\title{
Elektromos hajtású tanszéki versenyautó járműdinamikai modellezése
} \section{Vehicle dynamics modelling of an electric driven race} car

\author{
A. SzÁNTó ${ }^{1}$, G.Á. SzíKI ${ }^{2}$, S. HAJDU ${ }^{3}$ \\ 1Debreceni Egyetem, szanto930922@freemail.hu \\ 2Debreceni Egyetem, szikig@eng.unideb.hu \\ 32Debreceni Egyetem, hajdusandor@eng.unideb.hu
}

Absztrakt: A következőkben egy MATLAB környezetben kifejlesztett jármüdinamikai szimulációs programot ismertetünk. A program a múszaki adatokból, mint bemenő paraméterekből, előállítja a jármú menetdinamikai függvényeit, és közvetve alkalmas a müszaki paraméterek optimalizálására. A programot a DE MK Gépészmérnöki Tanszékén tervezett és kivitelezett elektromos meghajtású versenyautóra már sikeresen alkalmaztuk.

Abstract: In the following we are presenting a vehicle dynamics simulation program developed in MATLAB environment. The program is capable of calculating the dynamics functions of a vehicle from its technical data. The program has been successfully applied for the optimization of the technical data of an electric driven race car that was designed and constructed at the Department of Mechanical Engineering of the University of Debrecen.

\section{Az MVM futam}

Az elmúlt években egyre gyakrabban esik szó arról, hogy Földünk és lakossága egy súlyos problémával szembesül: környezetünk szennyezésével, amely napjainkban is folytatódik. A közúti közlekedés jelenlegi formájában az egyik legjelentősebb környezetszennyező. Ma már léteznek olyan technológiák [1], amelyek forradalmasíthatják az ehhez használt járműveket és egyéb eszközöket, ezáltal csökkentve a káros anyag kibocsátást. Ezen technológiák fejlődéséhez természetesen további kutatások szükségesek.

Az MVM futam a környezetbarát technológiákon alapuló, alternatív hajtású járművek versenye. A rajthoz álló járművek alkotói fiatal szakemberek, többnyire mérnökhallgatók, akiket munkájukban kisebb-nagyobb cégek, egyetemi tudásközpontok, tanszékek segítenek. [2] A 2014. és 2015. évi versenyeken a DE MK Gépészmérnöki Tanszékén kifejlesztett versenyautóval már szerepeltünk, 2. és 1. helyezést érve el. 
DOI: 10.21791/IJEMS.2016.2.14.

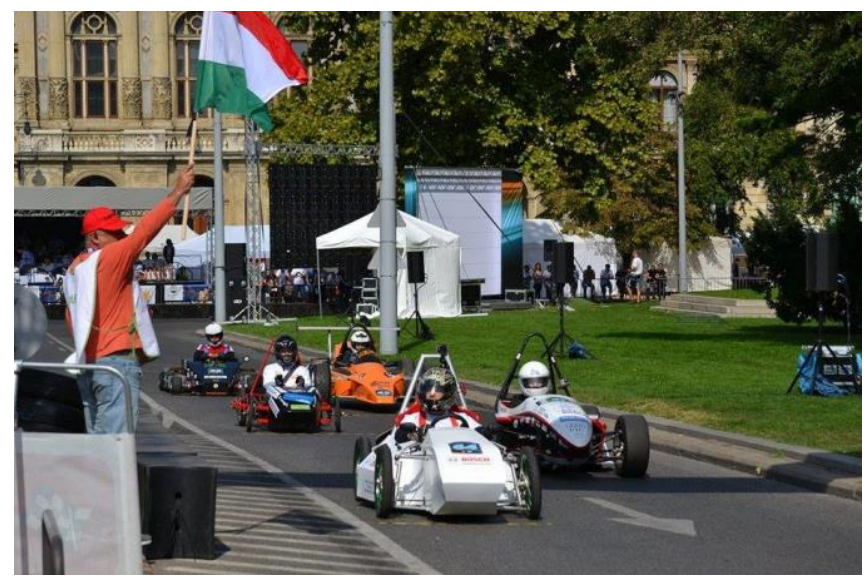

1. ábra: A 2015-ös MVM futam rajtja, első helyen a gépészmérnöki tanszék versenyautója

\section{A szimulációs program célja}

A minél eredményesebb versenyzés érdekében fontos a jármű műszaki paramétereinek összehangolása. Ezeken belül kulcsfontosságú a hajtáslánc optimalizálása. Ebből a célból kifejlesztettünk egy szimulációs programot, melynek segítségével meghatározhatóak azon optimális (pl. a lánchajtást, futóművet, a jármű súlyeloszlását jellemző) műszaki paraméterek, amelyekkel a kitűzött menetdinamikai célok (pl. a versenytáv megtétele a legrövidebb idő alatt) elérhetők.

\section{A versenyautó}

Az autó az MVM futam „Prototípus” kategóriára vonatkozó versenyszabályzatnak megfelelően készült, és először a 2014. évi versenyen szerepelt. A jármű váza egy alumínium csövekből illetve zártszelvényekből összehegesztett térhálós szerkezet, amelyhez egy független, kettős kereszt lengőkaros első kerékfelfüggesztés, valamint az önállóan rugózó hátsó hajtóegység kapcsolódik. Az utóbbi magába foglalja a motort, motorvezérlést, lánchajtást, és a hátsó kerekeket. A vázszerkezet részét képezi még a járművezető mellett két oldalon kialakított akkumulátortartó, valamint a biztonsági szempontok figyelembe vételével kialakított bukókeret.

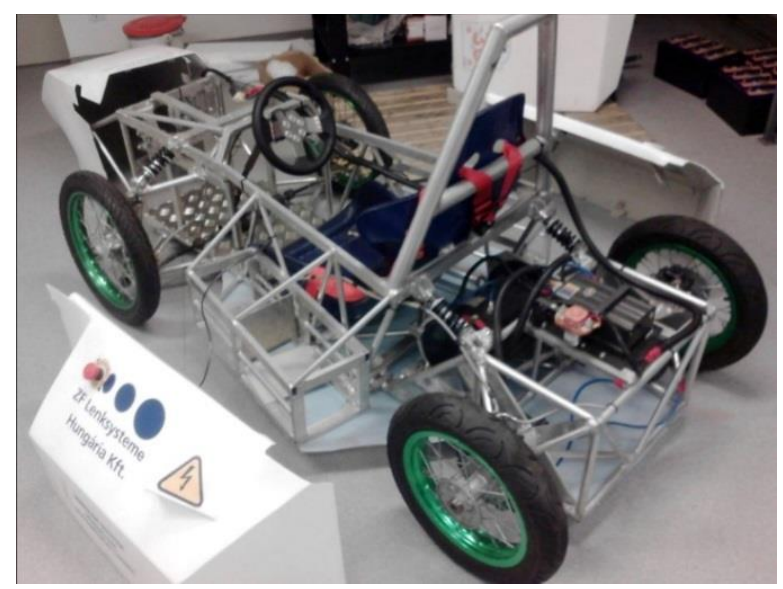

2. ábra: Az autó jelenlegi állapota, burkolat és akkumulátor nélkül 
DOI: 10.21791/IJEMS.2016.2.14.

A hajtásról egy soros gerjesztésű, 4 kW-os egyenáramú motor [3] gondoskodik, amely lánchajtáson keresztül adja át a nyomatékot a meghajtott, kúpgörgőkkel csapágyazott hátsó tengelynek, és az ahhoz mereven kapcsolódó keréknek. A jármű lassításáról kétkörös fékrendszer gondoskodik kerekenként külön tárcsafékkel.

\section{A dinamikai modell}

A szimulációs programhoz egy olyan járműdinamikai modellt dolgoztunk ki, amelyben az autót négy, egymással szoros kapcsolatban lévő szerkezeti egységre bontjuk. Jelenleg az autónak csak a jobb hátsó kereke hajtott, de a közel jövőben a bal hátsó kereket is hajtottá kívánjuk tenni, így a modellt már erre a „végleges” elrendezésre dolgoztuk ki. Ennek figyelembe vételével a fent említett szerkezeti egységek az alábbiak:

1) meghajtott hátsó kerekek, és az azzal együtt forgó alkatrészek;

2) szabadon futó első kerekek, valamint az azokkal együtt forgó alkatrészek;

3) járműfelépítmény valamint a motor állórésze;

4) motor forgórésze.

Ezen szerkezeti elemekre külön-külön mozgásegyenleteket írunk fel, a külső erők és nyomatékok mellett figyelembe véve a különböző szerkezeti elemek között fellépő (belső) erőket és nyomatékokat (Newton III. törvénye alapján).
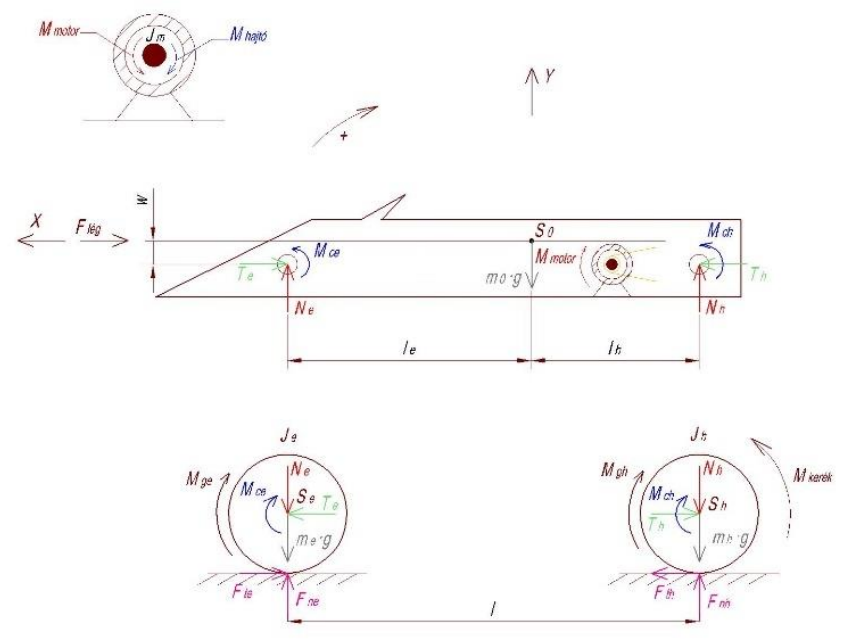

3. ábra: A versenyautó különböző szerkezeti egységeire ható erők és nyomatékok 
Ezt követően felírhatjuk a jármű egyes szerkezeti egységeire vonatkozó mozgásegyenleteket:

Mozgásegyenletek a szabadon futó első kerekekre és az azokkal együtt forgó alkatrészekre:

I. $\sum_{i} \mathrm{~F}_{\mathrm{ix}}=\mathrm{T}_{\mathrm{e}}-\mathrm{F}_{\mathrm{te}}=\mathrm{m}_{\mathrm{e}} \cdot \mathrm{a}_{\mathrm{s}} \rightarrow T_{e}=m_{e} \cdot a_{s}+F_{t e}$

II. $\sum_{i} \mathrm{~F}_{\mathrm{iy}}=\mathrm{F}_{\mathrm{ne}}-\mathrm{N}_{\mathrm{e}}-\mathrm{m}_{\mathrm{e}} \cdot \mathrm{g}=0$

III. $\sum_{i} \mathrm{M}_{\mathrm{i}\left(\mathrm{s}_{e}\right)}=\mathrm{M}_{\mathrm{ge}}+\mathrm{M}_{\mathrm{ce}}-\mathrm{F}_{\mathrm{te}} \cdot \mathrm{R}=\mathrm{J}_{\mathrm{e}} \cdot \varepsilon_{e}$

Mozgásegyenletek a meghajtott hátsó kerekekre és az azokkal együtt forgó alkatrészekre:

IV. $\sum_{i} \mathrm{~F}_{\mathrm{ix}}=\mathrm{F}_{\mathrm{th}}-\mathrm{T}_{\mathrm{h}}=\mathrm{m}_{\mathrm{h}} \cdot \mathrm{a}_{\mathrm{s}} \rightarrow T_{h}=-m_{h} \cdot a_{s}+F_{t h}$

V. $\sum_{i} \mathrm{~F}_{\mathrm{iy}}=\mathrm{F}_{\mathrm{nh}}-\mathrm{N}_{\mathrm{h}}-\mathrm{m}_{\mathrm{h}} \cdot \mathrm{g}=0$

VI. $\sum_{i} \mathrm{M}_{\mathrm{i}\left(s_{h}\right)}=\mathrm{M}_{\mathrm{gh}}+\mathrm{M}_{\mathrm{ch}}+\mathrm{F}_{\mathrm{th}} \cdot \mathrm{R}-\mathrm{M}_{\text {kerék }}=\mathrm{J}_{\mathrm{h}} \cdot \varepsilon_{h}$

Mozgásegyenletek a járműfelépítményre:

VII. $\sum_{i} \mathrm{~F}_{\mathrm{ix}}=T_{h}-\mathrm{T}_{\mathrm{e}}-F_{\text {lég }}=\mathrm{m}_{0} \cdot \mathrm{a}_{\mathrm{s}}$

VIII. $\sum_{i} \mathrm{~F}_{\mathrm{iy}}=\mathrm{N}_{\mathrm{e}}+\mathrm{N}_{\mathrm{h}}-\mathrm{m}_{0} \cdot \mathrm{g}=0$

IX. $\sum_{i} \mathrm{M}_{\mathrm{i}\left(s_{0}\right)}=\mathrm{M}_{\text {motor }}-\left(\mathrm{M}_{\mathrm{ce}}+M_{c h}\right)+\mathrm{N}_{\mathrm{e}} \cdot l_{e}-\mathrm{N}_{\mathrm{h}} \cdot l_{h}-T_{e} \cdot \mathrm{w}+T_{h} \cdot \mathrm{w}=0$

Mozgásegyenlet a motor forgórészére (csak forgómozgásra):

$$
\text { X. } \quad-M_{\text {motor }}+M_{\text {hajtó }}=J_{m} \cdot \varepsilon_{m o t}=J_{m} \cdot i_{12} \cdot \varepsilon_{h}\left(\varepsilon_{h}=\varepsilon_{m o t} \cdot \frac{1}{i_{12}}\right)
$$

\section{A „slip” figyelembevétele a hátsó kerekeknél:}

A „slip” a kerékcsúszás mértéke, amelyet az alábbi összefüggés értelmez:

$$
\text { slip }=\frac{\omega_{h} \cdot R-v_{s}}{v_{s}} \cdot 100 \%
$$

Ahol: $\omega_{h}, R$ és $v_{s}$ a hátsó kerék szögsebességének nagysága, sugara és középpontjának sebességnagysága. A talaj által a hátsó kerekekre kifejtett súrlódási és nyomóerő hányadosát (azaz a súrlódási tényezőt) megadhatjuk a „slip” függvényében. Erre vonatkozik az alábbi, un Pacejka „Varázsformula” [4, 8, 9]:

$$
\frac{F_{t h}}{F_{n h}}=\mu=c_{1} \cdot \sin \left(c_{2} \cdot \operatorname{atan}\left(c_{3} \cdot \operatorname{slip}-c_{4} \cdot\left(c_{3} \cdot \operatorname{slip}-\operatorname{atan}\left(c_{3} \cdot \operatorname{slip}\right)\right)\right)\right)
$$

Ahol a $c_{1}, c_{2}, c_{3}$ és $c_{4}$ konstansokat méréssel kell meghatározni. 


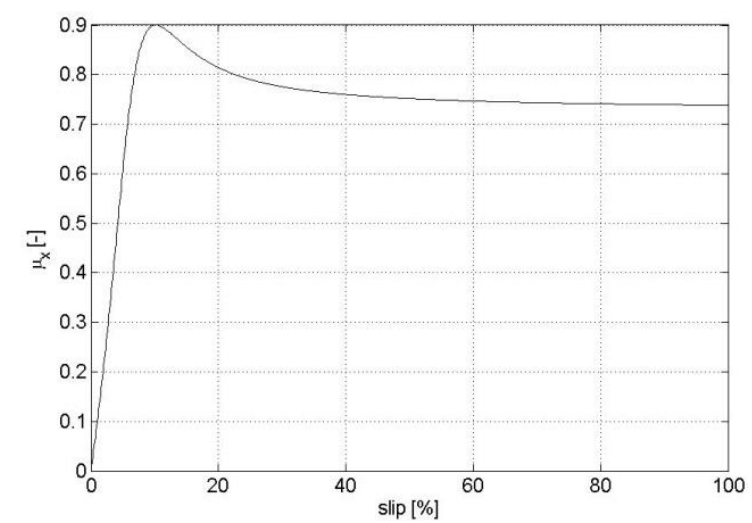

4. ábra: A Pacejka „varázsformula” grafikonja $c_{1}=0,9, c_{2}=1,4, c_{3}=7,936, c_{4}=-10$ értékek esetén

\section{A szimulációs program}

Az ismertetett dinamikai modellre alapozva a Matlab [5] szoftver alkalmazásával létrehoztunk egy szimulációs programot, amely az irodalomból ismert és kísérletileg meghatározott műszaki adatokból, mint bemenő paraméterekből kiszámítja a versenyautó menetdinamikai jellemzőit.

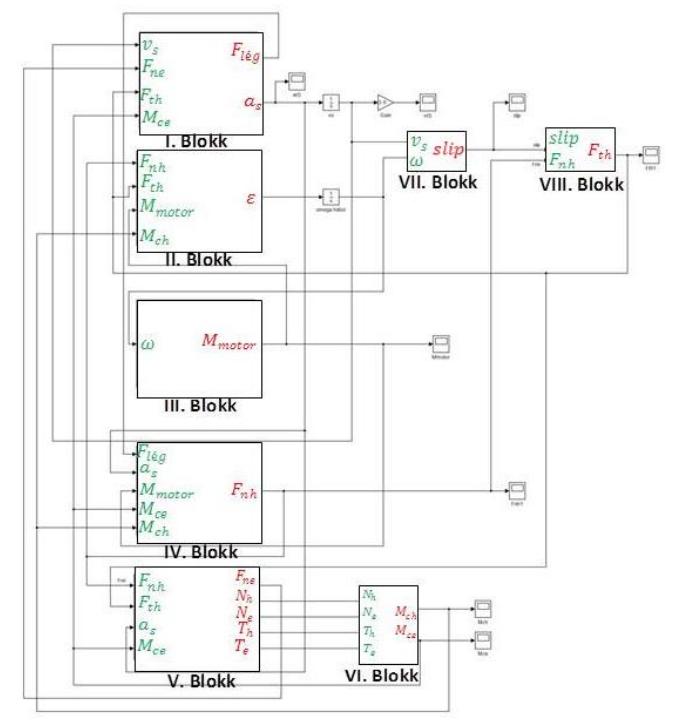

5. ábra: A szimulációs program blokkdiagramja

\section{A program bemenő paramétereinek kísérleti meghatározása}

A szimulációs program bemenő paraméterei között vannak olyanok, amelyek meghatározásához összetett mérési eljárás szükséges. Ezen paraméterek egy részét már meghatároztuk (motor karakterisztika, tömegek, tehetetlenségi nyomatékok, a jármű súlypontjának meghatározása) a többit (gördülési ellenállási kar, csapágy és légellenállási tényező) a későbbiekben tervezzük. 


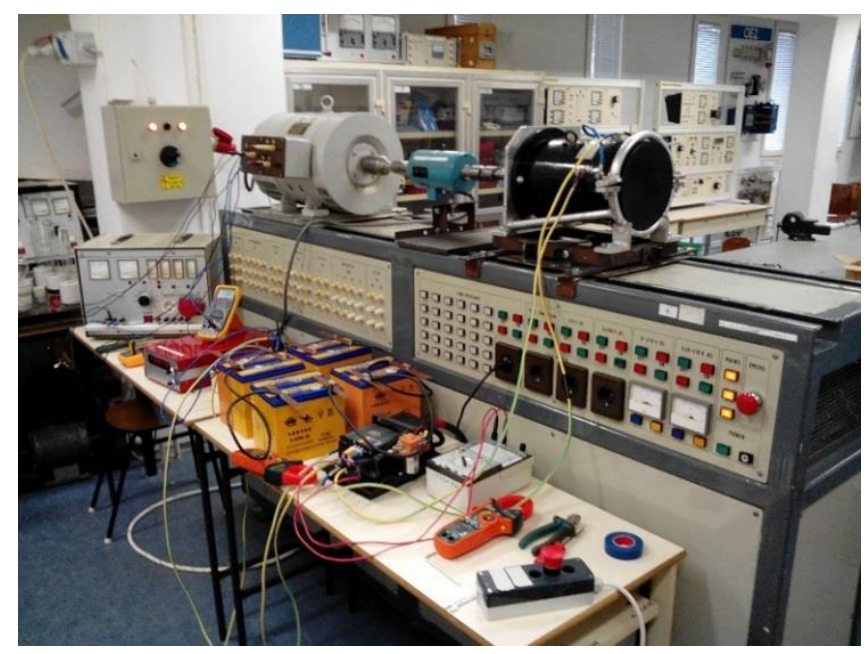

6. ábra: A motor karakterisztika mérése

\section{A program által szolgáltatott menetdinamikai függvények}

A programmal előállítható menetdinamikai függvények az alábbiak:

- A jármű gyorsulása, sebessége és az általa megtett út a menetidő függvényében.

- A talaj által a jármű kerekeire kifejtett tangenciális és normális irányú erők a menetidő függvényében.

- A tangenciális és normál irányú tengelyterhelések a menetidő függvényében.

- A gördülési és csapágy ellenállási nyomatékok a menetidő függvényében.

- A légellenállási erő az idő függvényében.

- Kerékcsúszás („slip”) a menetidő függvényében.

A fenti függvényekből példaként most bemutatunk néhányat különböző bemenő paraméterek rögzítése mellett. Az 7. ábra a versenyautó hátsó kerekeinek kerületén fellépő vonóerőt mutatja a menetidő függvényében, különböző láncáttételek esetén. Az áttételen kívül minden más bemenő paraméter egyezik a három esetben.

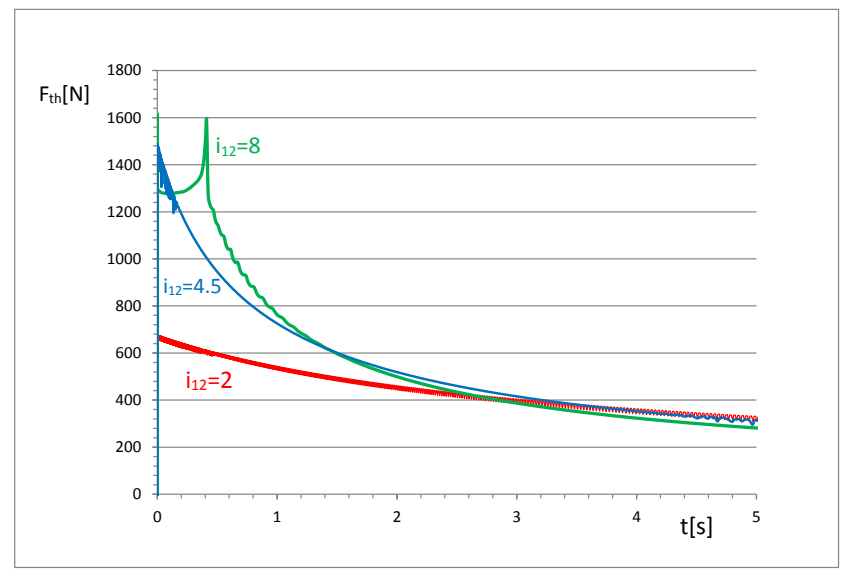

7. ábra: A hátsó kerekek kerületén fellépő vonóerő a menetidő függvényében különböző láncáttételek mellett ábrázolva 
A 8. ábra a versenyautó sebesség-idő függvényeit szemlélteti ugyanazon láncáttételek mellett.

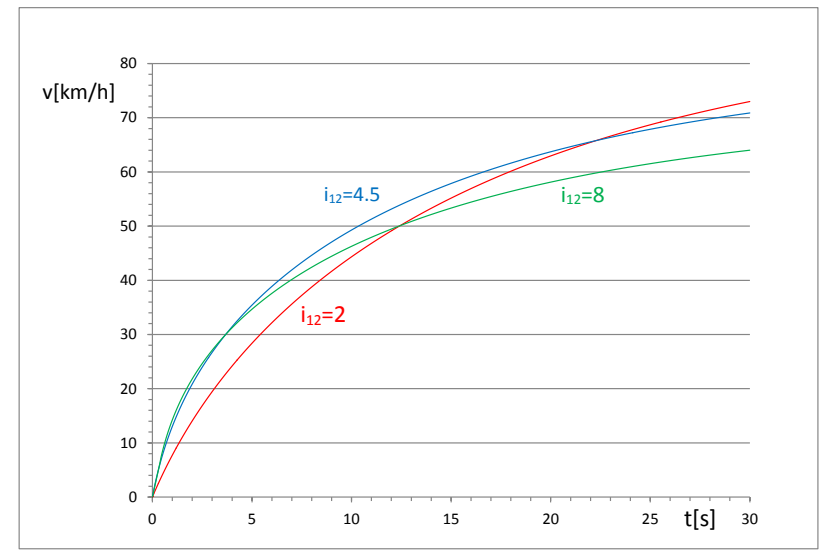

8. ábra: Sebesség-idő függvények különböző láncáttételek mellett

A 9. ábrán a versenyautó első és hátsó kerekeire ható nyomóerőket ábrázoltuk a menetidő függvényében ugyanazon bemenő paraméterértékek esetén.

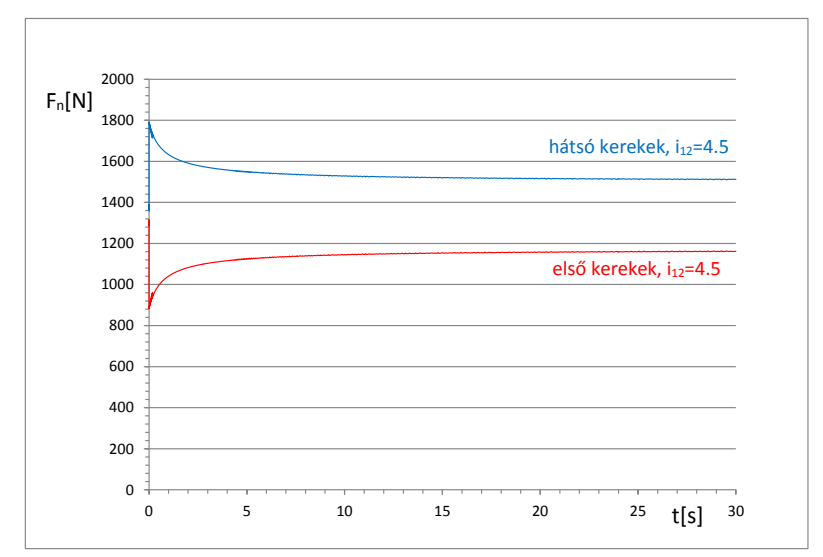

9. ábra: Az első és hátsó kerekekre ható nyomóerő a menetidő függvényében

\section{A program alkalmazása egy optimalizálási feladatra}

A szimulációs program fő célja, hogy segítségével meghatározzuk azon optimális műszaki adatokat, amelyekkel a legjobb menetdinamikai tulajdonságok érhetők el. Természetesen különböző versenyfeladatokhoz különböző optimális értékek tartoznak. Más értékek lesznek ideálisak például egy hosszú távú körverseny, vagy egy rövid távú (pl. 200m hosszú) gyorsulási verseny esetén. A továbbiakban példaként a gyorsulási verseny esetével foglalkozunk két paraméterre elvégezve az optimalizálást. A két paraméter egyike a jármű súlypontjának hátsó tengely től mért vízszintes irányú távolsága, a másik a láncáttétel értéke. A többi paraméter értékét a versenyautóban jelenleg alkalmazott értékekben rögzítettük. Az optimalizálás elve az, hogy a láncáttétel értékét, valamint a súlypont hátsó tengelytől mért távolságát a [2;8] és [0;0,675][m] tartományokban változtatva megkeressük azon optimális értékpárokat, amelyekkel álló helyzetből indulva legrövidebb idő alatt teljesíthető a 200m-es táv. 


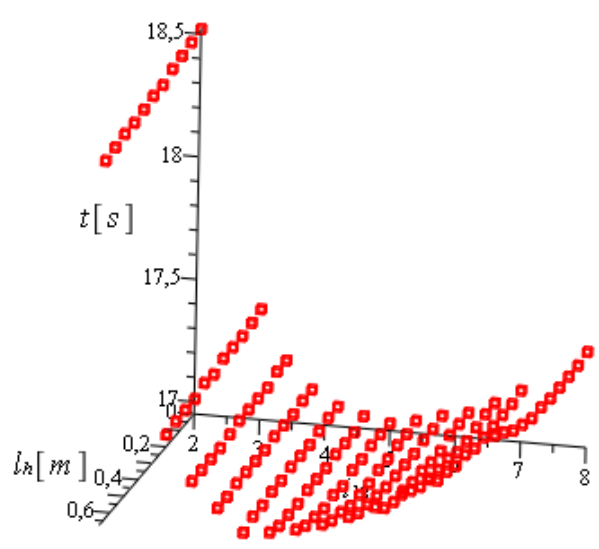

10. ábra: A 200 m-es táv megtételéhez szükséges menetidők a láncáttétel és a hátsó keréktől mért súlyponttávolság függvényében ábrázolva (forrás: [6])

Az eredményekből leolvasható, hogy a minimális menetidő akkor érhető el, ha a jármű súlypontja a hátsó tengelytől 0,34 - 0,47m távolságban van, és 5-ös érték körüli láncáttételt alkalmazzuk.

\section{Összefoglalás}

A TDK dolgozatban ismertetett szimulációs program - a fejlesztések jelenlegi szintjén - egyenes pályán gyorsító jármű menetdinamikai függvényeinek előállítására szolgál a járművet jellemző műszaki adatokból. A szokásos menetdinamikai függvények (gyorsulás-, sebesség- és út-idő függvény) mellett képes a talaj által a kerekekre kifejtett tangenciális és normális irányú erők, valamint tengelyterhelések időfüggésének számítására.

A program a jármű mozgását befolyásoló hatások (tényezők) szinte mindegyikét figyelembe veszi, így például a motor karakterisztikát, gördülési, csapágy és légellenállást, a forgó részek tehetetlenségi nyomatékait, a jármű súlypontjának helyét, valamint a kerék és talaj között fellépő súrlódási tényezőt a kerékcsúszás („slip”) függvényében.

A program működéséhez szükséges bemenő műszaki paraméterek egy részét a tanszékünkön tervezett és kivitelezett elektromos meghajtású versenyautó esetében már kísérletileg meghatároztuk, ilyenek a motor karakterisztika, a forgó részek tehetetlenségi nyomatékai valamint a jármű súlypontja. A hiányzó paraméterek meghatározását a jövőben tervezzük.

A program egyenes pályán történő gyorsítás esetén már jelenlegi formájában is alkalmazható a legkedvezőbb menetdinamikai tulajdonságokat biztosító optimális műszaki paraméterek meghatározására. Ezt egy két paraméteres optimalizálási feladat formájában be is mutattuk a TDK dolgozatban.

A jövőben tervezzük a program tovább fejlesztését egy teljes, kanyarokat is tartalmazó versenypályára, amely gyorsítási és fékezési szakaszokat egyaránt tartalmaz. A végső célunk egy új tanszéki versenyautó tervezése és megépítése, amelyet már a tovább fejlesztett programunk által meghatározott optimális műszaki paraméterekre alapoznánk. 
International Journal of Engineering and Management Sciences (IJEMS) Vol. 1. (2016). No.2.

DOI: 10.21791/IJEMS.2016.2.14.

\section{Hivatkozások}

[1] Zöldy Máté, Emőd István, Tölgyesi Zoltán: Alternatív járműhajtások - Maróti Könyvkereskedés és Könyvkiadó Kft. (2006) ISBN 9639005738

[2] http://energiafutam.ahjv.hu/content/index/id/1/m/5

[3] http://webaruhaz.permanent.hu/termek/elektromos_auto-1-motorok135/dc48v_os_4kw_os_soros_villanymotor-187

[4] Hans B. Pacejka, Igo Besselink: Tire and Vehicle Dynamics (Third edition) - Published by Elseiver Ltd. (2012) ISBN 978-0-08-097016-5.

[5] Matlab 2014b, The MathWorks, Inc, Natick, Massachusetts, United States.

[6] Maple 13.0, Copyright (C) Maplesoft, a division of Waterloo Maple Inc. 1981-2009.

[7] Ilosvai Lajos: Járműdinamika (2013)

[8] Jörsen Reimpell, Jürgen W. Betzler, Bári Gergő, Hankovszki Zoltán, Kádár Lehel, Lévai Zoltán, Nagyszokolyai Iván: Gépjármű futóművek I. (2012) ISBN 978-963-279-606-2

[9] Bernd Heissing, Metin Ersoy: Chassic Handbook (2011) ISBN 978-3-8348-0994-0 